\title{
AN ANALYSIS OF THE CONDITION OF THE TOURIST BRAND AND TOURIST ATTRACTIVENESS OF THE PODKARPACKIE REGION BASED ON THE BRAND ASSET VALUATOR MODEL
}

\author{
BEATA GIERCZAK-KORZENIOWSKA
}

\author{
University of Rzeszów, Institute of Economics and Finance at the College of Social Sciences, Rzeszów, Poland
}

\author{
Mailing address: Beata Gierczak-Korzeniowska, University of Rzeszów, Institute of Economics and Finance \\ at the College of Social Sciences, 2 Ćwieklińskiej Street, 35-601 Rzeszów, tel.: +48 178721604 , \\ e-mail: beatagierczak@ur.edu.pl
}

\begin{abstract}
Introduction. There are many factors which determine the attractiveness of a region for tourists. However, such assessments are, relatively rarely, a result of the analysis of the presence and condition of regional tourist brands and their perception among visitors. The analysis and assessment of the condition of a brand can be carried out using the BAV (Brand Asset Valuator). This is an extremely interesting and useful tool which explains the dynamics of behaviour of brands on the market and diagnoses their "health", supporting the process of their long-term management. Materials and methods. On the basis of the results of a pilot study, an attempt is made to measure the tourist attractiveness of the Podkarpackie region through the assessment of regional tourist brands and their features which are important from the point of view of the inhabitants of the region. The BAV model was used to analyse 32 tourist products. The applied research methods include the Mann-Whitney test, Spearman's rank correlation coefficient, and the chi-square independence test. Results. The mapped data analysis based on the BAV model showed that 16 out of 32 products assessed were located in the leadership quadrant. The majority of the remaining products were in the development or decline phases. Conclusions. The presence of branded tourist products and their number have an impact on the tourist attractiveness of the region. The following aspects of the region were considered the most attractive: nature (natural surroundings, natural values, and ecological aspects), heritage (historical heritage and monuments and presentation of important past events), and tourism (tourism and recreation offerings).
\end{abstract}

Keywords: tourist brand, Brand Asset Valuator, tourist attraction, Podkarpackie region

\section{Introduction}

The presence of an interesting and exciting tourist product in a given area is of value to both its product managers and tourists. Making use of the brands present in a given tourist destination contributes to the improvement of its image in the eyes of tourists, making its offer more competitive. It is the branded products existing in a given area which help, inter alia, strengthen and increase its so-called perceived attractiveness [1]. Hence, we can notice an increase in the activities and cooperation of many entities to achieve the desired result in the process of brand management of the tourist destination. At the same time, the process of creating and strengthening brands which guarantee quality service is observed in this respect [2]. A strong and recognisable brand is every region's asset; therefore, building strong brands is a priority in management $[3,4]$.

When it comes to branding, as S. Pike [5] emphasises, it plays an invaluable role on the market. According to him, modern consumers have many more products to choose from than ever before. The problem they face is that they do not have too much time to make the right decision. Therefore, knowledge of the brand makes it easier to make decisions, reduces the risks associated with buying, creates expectations about benefits, and delivers promises. A brand is a good or service which provides benefits and brings an added value that the consumer appreciates enough to choose a particular product. The added value lies in certain brand features arising in the mind of the consumer, which add value resulting from personal experiences related to goods or services [6].
This phenomenon is related to the multifaceted positioning model proposed by Ajzen and Fishbein [7], according to which the attitude people adopt towards an object is the result of their beliefs about specific attributes and values the object possesses, as well as values assigned to those features. It is assumed that consumers will choose the option towards which they exhibit the most positive attitude by expressing the highest index of subjective utility (the sum of features multiplied by their validity). This model is the theoretical basis of U \& A (Use \& Attitude) marketing research [8]. The multi-aspect positioning model has an advantage over the direct evaluation of the object because it allows one to determine the causes of a weak or strong attitude towards the object. Looking from the perspective of the maximisation of a company's profit, in turn, understanding these causes allows for more flexibility in the implementation of effective marketing activities aimed at changing the attitude towards a brand to an optimal one [9].

What is helpful in the diagnosis of the "health" or condition of a brand is the BAV model, which is a pragmatic and original tool supporting the process of long-term brand management. A well-established brand should be responsible for abstract associations and symbols which occur in the minds of consumers and add value to products resulting from private beliefs [10]. A tourist region, in turn, is likely to become a significant symbol provided it has strong links with branded tourist products and is identified with them. This has a significant impact on the tourist attractiveness of the region, which is understood as a set of factors affecting the development of tourism in a specific tourist destination or a particular site or facility. It is also the sum of its 
tourist values, the way these values are managed, and transport accessibility in the area, as well as residents' attitudes towards tourists. This attractiveness has a considerable impact on tourists who choose their holiday destinations [11].

The main aim of the article is to assess the tourist attractiveness of the Podkarpackie region by means of the assessment of 32 regional tourist brands and their features, which are significant from the point of view of its inhabitants, including tourists, based on the BAV model. With a view to achieving this aim, two basic parameters of the BAV model, namely the strength of the brand and its potential, were estimated. Brand strength consists of its distinctiveness and the demand for it, while its potential is based on respect and knowledge. The supplementary purpose is to answer the question whether the presence of branded tourist products influences customers' decisions regarding the choice of the tourist destination.

\section{BAV model in tourism}

Among many models for brand evaluation which use marketing measures and research their impact on shareholder value, the BAV (Brand Asset Valuator) deserves special attention. The BAV was created by Young \& Rubicam advertising agency [https://www.yr.com/bav] as a result of one of the most extensive research programmes on brands ever undertaken.

A brand is an important element in the marketing structure of a tourist area. This mainly applies to the development of the brand's identity and its positioning [12]. The construction of a brand and its market success are based on four pillars (brand pillars), whose value is presented on a percentile scale. These include differentiation, relevance, esteem, and knowledge. The management of relationships among those four pillars is the key to brand health. The relationships illustrate the intrinsic value of the brand as well as its ability to generate margins and isolate itself from the competition [13]. The four pillars of branding make it possible to determine not only the general condition of the brand but also the phase of its development. The so-called PowerGrid, a matrix which illustrates a typical model of brand development, serves this purpose. The dimensions of the matrix are the brand's strength and its potential. The strength of the brand consists of its distinctiveness and the demand for it, while its potential is created by respect and knowledge [14].

Two groups of criteria for brand differentiation can be distinguished, including perceptual and economic ones. Perceptual criteria concern the need to create a certain state of consciousness in a potential buyer regarding the existence of distinguishing elements. The assumption is that the difference between brands must be recognisable to consumers, and the benefits of this differentiation must be desirable, meeting the needs or desires which are of importance to consumers [6]. Brand awareness is also one of the factors determining the brand's strength and, consequently, its value [15]. It includes recognition and memory. Brand recognition is the consumer's ability to confirm previous contact with the brand at the time of re-contact. This means they are able to indicate a familiar brand from a group of brands of a given product (so-called assisted awareness). Memory means the consumer's ability to remember the name of the brand when the product category is given or the need is satisfied by the given product category. The consumer can name the brand as one of several known to them in a given product category (so-called spontaneous consciousness) [16]. On the other hand, economic criteria related to price differences are important from the point of view of the profitability of the business [6].
The fact that a tourist region has a recognisable and strong brand brings many benefits, the key ones being the following according to A. Panasiuk [17]:

- increased awareness and recognition of the tourist destination;

- greater interest of tourists in the area, which contributes to an increase in the tourist growth rate, enhances the use of the area, increases the development of tourism in the area, and reduces the effects of seasonality;

- increased number of loyal tourists who show greater understanding for price increases, which guarantees even the off-season popularity of the area [18, 19];

- increased market share;

- improved competitiveness of the region;

- greater attractiveness of investment in the region;

- increased budget revenues for local governments located within the boundaries of the tourist region;

- improvement in the quality of life of the inhabitants of the region;

- stimulating impact on other sectors of the economy within the area.

For owners of the researched brands, the BAV is an early warning tool, but, more importantly, it helps to rebuild the value of a brand. This is very important because, as stated by Stephen King (WPP Group, London), in contrast to products, brands can be unique and timeless and are essentially what the consumer buys [20].

The Brand Asset Valuator model makes it possible to create a map (grid) of brands, showing their current position and potential, thanks to which brands can be compared in one or several categories, within one or many countries or regions and among different consumer groups. Determining the position of brands in individual dimensions serves as an assessment of how well a given brand is advanced in its development and which area has not been fully developed [21].

The BAV model, which is based on its four main pillars, can be used in building a strong tourist brand [22]. Competing for tourists on a regional and global market requires constantly building the image of the brand of a place (region) by undertaking a series of activities involving many entities. Unfortunately, that multiplicity and diversity of entities involved in the creation of the region's tourist brand or brands often causes numerous problems and difficulties. The primacy of the entities' own interests often obscures the most important one, which is the good of the tourist region and the tourist. The BAV theory assumes that the image or familiarity indicators alone are definitely not enough to evaluate the current condition of the brand or its strength to continue to develop and grow. Brands which are successful and function well in a competitive environment have unique features which give them a special character and define their identity [23].

The creation of a strong tourist brand requires a shift from a narrow definition of a tourist product to a broad one and the creation of a brand which all local entities, namely the public sector, private service providers, and the residents, would identify with $[24,25]$.

\section{Tourist attractiveness of Podkarpackie region and condi- tion of tourist brand - material and methods}

The aim of the research was to assess and analyse the tourist attractiveness of the Podkarpackie region. Usually many factors determine the attractiveness of a region for tourists. However, this assessment is relatively rarely the result of an analysis of 
the presence and condition of regional tourist brands and their perception among visitors. Therefore, 32 most popular branded tourist products located in the Podkarpackie region were selected for the pilot study. The research was conducted between August and December 2017 in the Podkarpackie region. Data were collected using questionnaires.

Due to the nature of the issue, the test sample was selected to meet the diversity requirement, which is also a prerequisite for the objectivity of the research results. For this purpose, inter alia, random selection and convenience sampling were used in the current pilot study. In addition, an absolute minimum was set in the form of 200 correctly filled questionnaires, the result of which was the rejection of 14 forms out of the 214 ones distributed. The demographic characteristics of the respondents were as follows:

1. $60 \%$ were women, and $40 \%$ were men;

Table 1. Evaluation of 32 branded products in the Podkarpackie region based on the BAV model

\begin{tabular}{|c|c|c|c|c|c|c|c|c|}
\hline Tourist products & D & $\mathbf{R}$ & E & $\mathrm{K}$ & $\begin{array}{c}\text { Brand } \\
\text { potential } \\
(E+K)\end{array}$ & $\begin{array}{c}\text { Brand } \\
\text { strength } \\
(D+R)\end{array}$ & $\begin{array}{c}\text { Brand } \\
\text { assessment }\end{array}$ & $\begin{array}{l}\text { Brand } \\
\text { position }\end{array}$ \\
\hline Bieszczady Mountains & 4.26 & 3.91 & 4.04 & 4.22 & 4.08 & 4.13 & 4.11 & 2 \\
\hline Open Air Museum in Sanok & 3.69 & 3.63 & 3.54 & 3.53 & 3.66 & 3.54 & 3.60 & 12 \\
\hline Carpathian Troy Archaeological Open Air Museum & 3.14 & 2.96 & 2.94 & 2.67 & 3.05 & 2.80 & 2.93 & 26 \\
\hline Łańcut Castle & 4.20 & 4.12 & 4.31 & 4.26 & 4.16 & 4.28 & 4.22 & 1 \\
\hline City of Rzeszów & 3.53 & 3.62 & 3.60 & 4.34 & 3.58 & 3.97 & 3.77 & 4 \\
\hline Solina Lake & 3.97 & 3.92 & 4.02 & 4.24 & 3.94 & 4.13 & 4.03 & 3 \\
\hline Bieszczady railway bikes & 3.38 & 3.21 & 2.96 & 2.84 & 3.29 & 2.90 & 3.10 & 24 \\
\hline Church in Haczów & 2.78 & 2.63 & 2.66 & 2.38 & 2.70 & 2.52 & 2.61 & 30 \\
\hline Przemyśl Fortress & 3.38 & 3.18 & 3.21 & 3.17 & 3.28 & 3.19 & 3.23 & 17 \\
\hline Baranów Sandomierski & 3.02 & 2.98 & 3.02 & 3.00 & 3.00 & 3.01 & 3.00 & 25 \\
\hline Bóbrka - Museum of Petroleum & 3.31 & 3.13 & 3.07 & 3.01 & 3.22 & 3.04 & 3.13 & 23 \\
\hline Arłamów & 3.59 & 3.80 & 3.88 & 3.51 & 3.69 & 3.69 & 3.69 & 9 \\
\hline Monastery in Komańcza & 2.90 & 2.86 & 2.81 & 2.82 & 2.88 & 2.81 & 2.84 & 28 \\
\hline Hitler's Bunker in Stępina & 3.11 & 2.77 & 2.74 & 2.88 & 2.94 & 2.81 & 2.87 & 27 \\
\hline Arboretum in Bolestraszyce & 3.79 & 3.74 & 3.65 & 3.68 & 3.76 & 3.66 & 3.71 & 8 \\
\hline Wooden Architecture Route & 3.33 & 3.20 & 3.12 & 3.07 & 3.26 & 3.10 & 3.18 & 20 \\
\hline "Podkarpackie Smaki" Culinary Trail & 2.98 & 2.90 & 2.72 & 2.52 & 2.94 & 2.62 & 2.78 & 29 \\
\hline Chassidic Route & 2.24 & 2.07 & 2.09 & 1.76 & 2.15 & 1.92 & 2.04 & 32 \\
\hline Rzeźnicki Running Festival & 2.65 & 2.63 & 2.52 & 2.36 & 2.64 & 2.44 & 2.54 & 31 \\
\hline Glass Heritage Centre in Krosno & 3.41 & 3.27 & 3.35 & 3.20 & 3.34 & 3.27 & 3.30 & 16 \\
\hline $\begin{array}{l}\text { Ulma Family Museum of Poles Saving Jews in World War II in } \\
\text { Markowa }\end{array}$ & 3.66 & 3.53 & 3.59 & 3.38 & 3.59 & 3.48 & 3.54 & 13 \\
\hline Łańcut Music Festival & 3.73 & 3.81 & 3.86 & 3.52 & 3.77 & 3.69 & 3.73 & 5 \\
\hline Iwonicz-Zdrój & 3.67 & 3.73 & 3.70 & 3.81 & 3.70 & 3.75 & 3.73 & 6 \\
\hline Bieszczadzka Forest Railway & 3.55 & 3.48 & 3.50 & 3.55 & 3.52 & 3.53 & 3.52 & 14 \\
\hline Kalwaria Pacławska & 3.57 & 3.59 & 3.61 & 3.63 & 3.58 & 3.62 & 3.60 & 11 \\
\hline City of Przemyśl & 3.48 & 3.34 & 3.39 & 3.72 & 3.41 & 3.55 & 3.48 & 15 \\
\hline Castle in Krasiczyn & 3.68 & 3.56 & 3.55 & 3.72 & 3.62 & 3.63 & 3.63 & 10 \\
\hline Castle in Przemyśl & 3.21 & 3.11 & 3.16 & 3.24 & 3.16 & 3.20 & 3.18 & 19 \\
\hline Exhibition and Congress Centre in Jasionka & 3.10 & 3.24 & 3.24 & 3.02 & 3.17 & 3.13 & 3.15 & 22 \\
\hline Rymanów-Zdrój & 3.67 & 3.74 & 3.73 & 3.75 & 3.70 & 3.74 & 3.72 & 7 \\
\hline Horyniec-Zdrój & 3.21 & 3.27 & 3.23 & 3.13 & 3.24 & 3.18 & 3.21 & 18 \\
\hline Gallery of Zdzisław Beksiński in Sanok & 3.28 & 3.20 & 3.23 & 2.96 & 3.24 & 3.09 & 3.17 & 21 \\
\hline
\end{tabular}

Note: D - differentiation, $\mathrm{R}$ - relevance, $\mathrm{E}$ - esteem, $\mathrm{K}$ - knowledge.

Source: own research. 
2. $33.5 \%$ were aged $20-30,30.5 \%$ were aged $31-40,21.5 \%$ were aged $41-50,7.0 \%$ were aged 51-60, 6.0\% were aged 61-70, and $1.5 \%$ were aged over 71 ;

3. $66.0 \%$ had tertiary education, $29.5 \%$ had secondary education, $4.0 \%$ had vocational education, and $0.5 \%$ had primary education;

4. $63.0 \%$ lived in the city, $36 \%$ lived in the countryside, and $1.0 \%$ did not declare their place of residence.

\section{Results}

The assessment of individual branded products was preceded by questions related to respondents' general feelings and perceptions regarding the importance of branded products in the assessment of the tourist attractiveness of the Podkarpackie region as well as in their personal destination choice. All the respondents who answered the questions on the branded tourist products did so based on the following definition which was included in the questionnaire: "a branded product has a unique, positive identity; it is clearly distinguishable and more willingly chosen by customers; thanks to the brand, the tourist receives a guarantee of services at an appropriate quality level". Such a procedure was aimed at excluding discrepancies in the interpretation of the concept. In the first question, the respondents were to answer whether the number of branded tourist products in the Podkarpackie region has an impact on its tourist attractiveness. The vast majority (81\%) answered in the affirmative. A negative answer was provided for only $6 \%$ of the responses. The second question was more personal because the respondents had to decide whether the presence of branded tourist products influences their decisions regarding their choice of the destination/region. The majority $(70 \%)$ of the respondents gave an affirmative answer while for $22 \%$, the presence of branded products was irrelevant to choosing the destination.

The following question, constituting the main core of the questionnaire, concerned the evaluation of each of the 32 tourist products of the Podkarpackie region using the four pillars of the BAV model. All products were rated on a scale from 0 to 5 with respect to each of the pillars. Such a thorough analysis enabled further interpretation and determination of the condition of individual brands. Table 1 shows the average results of all the assessed tourist products along with two synthetic measures, namely, brand potential (average of D and R) and brand strength (average of E and K). The overall brand assessment (average of $\mathrm{D}, \mathrm{R}, \mathrm{E}$, and $\mathrm{K}$ ) and the place occupied by a given brand are given in the last two columns.

The best-rated products include the Bieszczady Mountains (2) and Solina Lake (3), known for their attractive nature, and Łańcut Castle (1) admired for its attractive heritage. The Chassidic Route and Rzeźnicki Running Festival are ranked last.

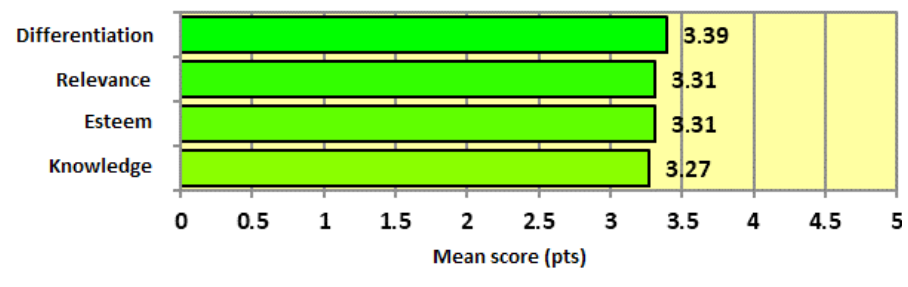

Source: own research

Figure 1. Total assessment of four pillars of the brand in relation to the 32 tourist products
Figure 1 shows the average score given by the respondents to all 32 branded tourist products in relation to the four pillars, that is the four basic dimensions, of the brand. It can be easily noticed that the average rating in each of the four aspects is very similar, which results from the fact that the respondents most often assessed brand differentiation, relevance, esteem, and knowledge on a similar level.

To have a fuller picture of the 32 brands analysed, one needs to analyse the relationship between the four pillars. An in-depth assessment can help predict the future potential growth of the brand or detect symptoms of its decline. Based on the individual dimensions, two new measures are created, so-called growth potential and current brand strength. A graph of the position of the brands (power grid), which illustrates the five stages of their development, is created by placing a measure of the current strength on the horizontal axis and the growth potential on the vertical axis. A brand that is being created will be located in the bottom left corner of the chart. At this stage, brands build their uniqueness and begin to be demanded. New brands usually move primarily to the top of the chart, but they are very rarely already widely-respected and known. After building high growth potential, the brand may remain in the area of unrealised potential as a niche brand, or it may transform its high growth potential into current strength and thus achieve the position of a leader. Properly managed brands have a chance to maintain their acquired potential for many years, at the same time maintaining their high current strength. When the brand has a lower growth potential than the current strength (quadrant 4 - potential loss), this indicates its weakness and potential loss of its market position. In the end, if the situation does not improve over time, it is very likely that its current strength will be weakened. In this situation, the group of loyal consumers of the brand is decreasing and, over time, fewer and fewer people recognise the brand. This may sometimes lead to its complete disappearance from the market.

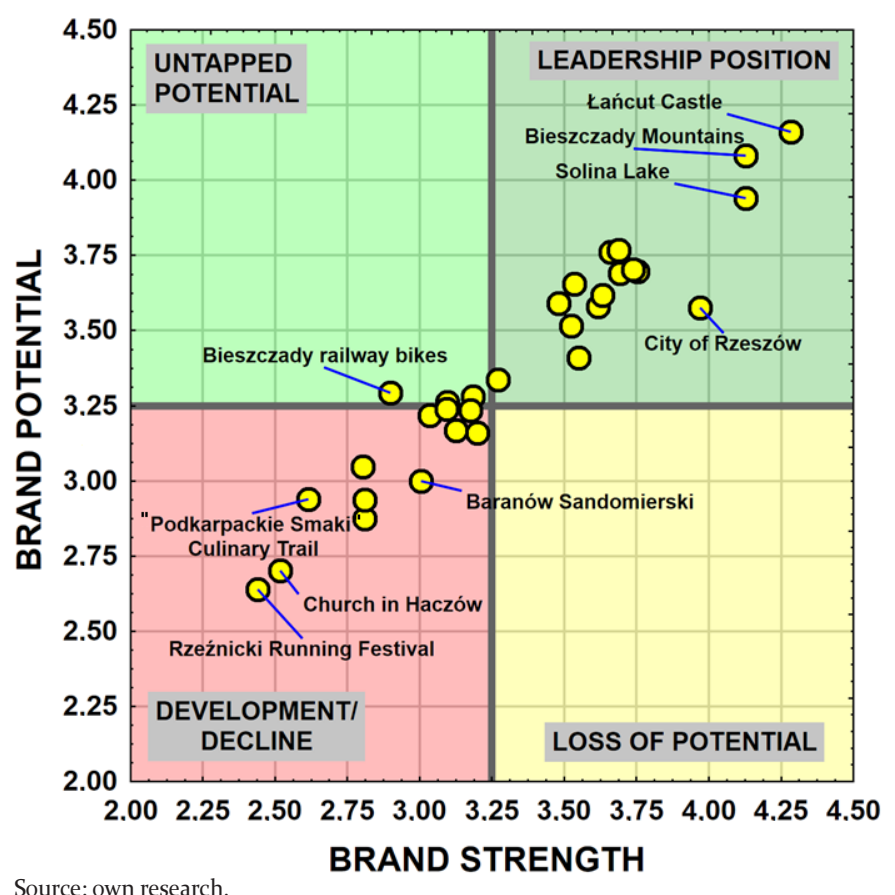

Figure 2. Map of 32 branded products in the Podkarpackie region based on the BAV model 
The scatter diagram (Fig. 2) shows the relationship between average brand potential and average brand strength for the 32 products which were assessed. The auxiliary lines determine the division of the studied population in terms of the relationship between the two measures. Since the two measures are very strongly correlated, almost all the products have, at the same time, high potential and brand strength, or low values of both measures. Selected brands which were most distant from the others are described in the chart. The leaders include Łańcut Castle, the Bieszczady Mountains, and Solina Lake, and the remaining 13 tourist products are located slightly lower. It can also be observed that none of the tourist products was found in quadrant 4 , related to the loss potential of a brand.

The attractiveness of the Podkarpackie region was also assessed based on an estimation of its attractiveness in particular categories. The results are presented in Figure 3 with categories ranked from those rated best to those rated worst. Nature in the region was rated best, with almost $80 \%$ positive evaluations in total. The lowest-ranking categories included business and sports, with under $40 \%$ of positive ratings. Such a result coincides not only with the individual assessment of the brands, which can be assigned to particular categories, but also with the number of branded products that fall within a given category. It should be noted that brand awareness is defined as the ability of a potential customer to recognise or recall that a given brand belongs to a specific product category. It is also one of the factors determining the strength of a brand and, consequently, its value [25]

The extent to which a region is attractive for tourists depends on their individual characteristics, for example, their values, attitude towards the destinations, education, age, possible disability, or social origin [5]. That is why the relationships between the respondents' age and their assessment of the attractiveness of the Podkarpackie region were examined using Spearman's rank correlation coefficient (Tab. 2).

Some correlations were statistically significant, which meant that age influenced the perception of the attractiveness of the Podkarpackie region. The negative signs of correlation coefficients mean that with age, the respondents' assessment of the attractiveness of the Podkarpackie region became lower. This is particularly evident while assessing its attractiveness in the business or heritage categories, and it concerns the sports category to the greatest extent. Such low ratings, especially in relation to sports and business, may be the result of the low activity of older people in those areas, due to their age, health problems, and professional inactivity.

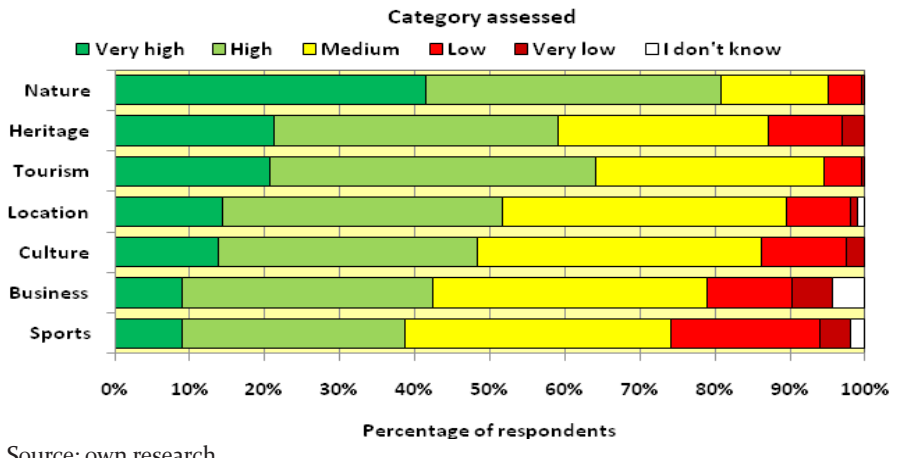

Source: own research.

Figure 3. Assessment of the degree of attractiveness of the Podkarpackie region by category

\section{Conclusions}

The creation of a competitive advantage based on brands is extremely important as brand value is now a key issue in the regional management process, and its knowledge is one of the main factors which determines the choice of tourist destination. This is crucial because, faced with an increasingly diversified choice of goods and services, consumers are becoming more and more conscious and search for security and quality assurance. They are less inclined to choose a destination for its novelty and more likely to choose one that is well known and guarantees quality and safety. Therefore, tourist regions which add value to their entities and increase their attractiveness are increasingly adopting a marketing concept focused on building strong brands.

The analysis conducted by the author has shown the following:

1. The consumer's choice of tourist destination is influenced by the presence of branded tourist products (as declared by $70 \%$ of the respondents).

2. The following aspects of the Podkarpackie region were considered most attractive: nature (natural surroundings, natural values, and ecological aspects), heritage (historical heritage and monuments and presentation of important past events), and tourism (tourism and recreation offerings).

3. The rating of the attractiveness of various areas of the Podkarpackie region decreased with age.

4. The number of branded tourist products in the region had an impact on its tourist attractiveness (according to $81 \%$ of the respondents).

5. Almost all the products had either high values of both brand strength and potential or low values of the two measures.

6. Close relationships could be observed between the position of branded products on the market, determined as a result of the application of the BAV model, and their assessment by the respondents.

In addition, and most importantly for the issue investigated, the mapped data analysis based on the BAV model showed that 16 out of 32 products tested were located in the leadership quadrant. The majority of the remaining products were in the development or decline phases. However, this does not mean that brands have inevitable lifecycles, which end with their earlier or later decline. Brands are more flexible than products, and it is possible to modify their image. Having an understanding of the process of the growth of brands and the loss of their market position makes it possible to properly manage brands

Table 2. Correlation between attractiveness of the Podkarpackie region assessed in particular categories and respondent age

\begin{tabular}{|c|c|}
\hline Category assessed & Age [years] \\
\hline Tourism & $\mathbf{0 . 1 2 ( p = 0 . 0 8 4 2 )}$ \\
\hline Business & $-0.17\left(p=0.0159^{\star}\right)$ \\
\hline Location & $-0.11(p=0.1200)$ \\
\hline Nature & $-0.03(p=0.6712)$ \\
\hline Culture & $-0.12(p=0.0879)$ \\
\hline Heritage & $-0.15\left(p=0.0300^{\star}\right)$ \\
\hline Sports & $-0.23\left(p=0.0013^{* *}\right)$ \\
\hline
\end{tabular}

Source: own research. 
and keep them in good condition for many years [21]. Assuming that the majority of the branded products researched in the current study are in the growth phase, it can be concluded that, at the moment, the attractiveness of the Podkarpackie region is assessed as average. It should also be borne in mind that these conclusions were drawn based on an assessment performed by the inhabitants of the region who know their products better than others.

The results presented in the article are part of the comprehensive research conducted by the author with the aim of measuring the attractiveness of the Podkarpackie region by means of assessing the condition of its branded tourist products based on the BAV model. It seems important to carry out further, indepth research with respect to the issue discussed in the article. Future analyses with the use of the BAV model should focus on the time of the presence of a given brand on the market and the impact of this time on its recognisability. In addition, it is recommended that the assessment of individual branded tourist products be conducted systematically using a fixed measurement tool. This would make it possible to show the dynamics of changes both in tourists' preferences and in the condition of individual brands.

\section{Acknowledgments}

This research was financed by the Polish Ministry of Science and Higher Education under the project "Using BAV in the Assessment Process of Tourist Attractiveness of the Podkarpackie Region" (Grant No. 10/WWF/PB/10/2017).

\section{Literature}

1. Kall J. (2001). Strong brand. Warszawa: PWE. [in Polish]

2. Rapacz A., Jaremen D.E. (2011). Tourist attractiveness as a factor in choosing a tourist destination. Ekonomiczne Problemy Usług 75, 131-141. [in Polish]

3. Marczak M. (2017). Branding of the tourist reception area and its application in the activities of national tourist organisations. Prace Naukowe UE we Wrocławiu 473, 325-338. DOI: 10.1561l/pn.2017.473.30 [in Polish]

4. Sasikala D. (2013). Brand Asset Valuator - Measuring brand value. International Journal of Social Science $\mathcal{E}$ Interdisciplinary Research 2 (6), 133-138.

5. Witek-Hajduk M.K. (2001). Brand management. Warszawa: Difin. [in Polish]

6. Aaker D.A. (1996). Building strong brands. New York: Free Press.

7. Górska-Warsewicz H. (2008). Strategies for building agritourism service branding. In G. Gołembski (ed.), New trends in tourism development (pp. 489-496). Sulechów: Wydawnictwo PWSZ w Sulechowie. [in Polish]

8. Urbanek G. (2000). Components of brand capital. Marketing i Rynek 6, 18-24. [in Polish]
9. Falkowski A., Tyszka T. (2009). Psychology of consumer behaviour. Gdańsk: GWP. [in Polish]

10. Ajzen I., Fishbein M. (1980). Understanding attitudes and predicting social behaviour. Englewood Cliffs, NJ: PrenticeHall.

11. Dagustani D., Buchory H. A., Satya M. T. (2014). The brand building: Developing Brand Asset Valuator and brand association (Empirical study on traditional snack food in Indonesia). International Journal of Business, Economics and Law 5(2), 58-69. DOI: 10.18488/journal.62/2016.3.2/62.2.18.30.

12. Kapferer J. N. (2005). The new strategic brand management. London: Kogan-Page.

13. Paszkiewicz A. (2009). An assessment of brand strength on the market based on the Brand Asset Valuator. Prace i Materiały Wydziału Zarządzania Uniwersytetu Gdańskiego 3/2, 479-488. [in Polish]

14. Fedyk W., Gruszka I., Krajewska-Smardz A. (2014). An assessment of the image of the Polish tourist brand according to foreigners. Rozprawy Naukowe AWF we Wrocławiu 45, 196-203. [in Polish]

15. Chhetri P., Arrowsmith C. (2008). GIS-based modelling of recreational potential of nature-based tourist destinations. Tourism Geographies 10(2), 233-257, DOI: 10.1080/14616680802000089.

16. Borzyszkowski J. (2015). Organisations managing tourist reception areas. Essence, functioning, directions of changes. Koszalin: Wydawnictwo Politechniki Koszalińskiej. [in Polish]

17. Panasiuk A. (2014). Tourist market. Structural study. Warszawa: Difin. [in Polish]

18. Light L. (1993). Brand erosion a waste of assets. Trust, quality and leadership important in creating lasting value. Business Marketing 8, 35-41.

19. Woods M., Deegan J. (2003). A warm welcome for destination quality brand: The example of Pays Cathare region. International Journal of Tourism Research 5, 269-282, DOI: doi.org/10.1002/jtr.436

20. Altkorn J. (1999). Brand strategy. Warszawa: PWE. [in Polish]

21. Falkowski A., Tyszka T. (2009). Psychology of consumer behaviour. Gdańsk: GWP. [in Polish]

22. Fedyk W., Gruszka I., Krajewska-Smardz A. (2014). An assessment of the image of the Polish tourist brand according to foreigners. Rozprawy Naukowe AWF we Wrocławiu 45, 196-203. [in Polish]

23. Van't Klooster E., Go F., Van Baalen P. (2004). Exploring destination brand communities: A business model for collaboration in the extremely fragmented tourism industry. In 17th International Bled eCommerce Conference - eGlobal, 21-23 June, Bled, Slovenia: University of Maribor.

Submitted: December 6, 2018. Accepted: April 25, 2019. 